\title{
Action Research of the Multiple Intelligence (MI), Cooperative Learning, and Game-based Teaching into Summer Intensive English Classes for Mixed-level and Mixed-age Students
}

\author{
Shu-Chin Su ${ }^{1, *}$, Eleen Liang ${ }^{2}$ \\ ${ }^{1}$ Department of English, the Danshui Campus of Aletheia University, Taiwan \\ ${ }^{2}$ Shengli Elementary School, Taiwan
}

Copyright $\bigcirc 2017$ by authors, all rights reserved. Authors agree that this article remains permanently open access under the terms of the Creative Commons Attribution License 4.0 International License

\begin{abstract}
This study is based on the '2014 the Schweitzer Program' in Taiwan which spanned for four weeks from the $2^{\text {nd }}$ to $29^{\text {th }}$ of August. The lessons included four classes of multimedia picture books and eight game-based lessons. The aim of this research is to describe how to integrate the theory of 'Multiple Intelligence (MI)' by Howard Gardner as well as the theories of 'Cooperative Learning', and 'Game-Based Teaching' into summer intensive English classes among mixed-level and mixed-age students. There were 20 participants composed of 13 fifth graders and seven sixth graders with equal members of each gender. The study followed a qualitative action research methodology with the use of interviews, documents and observations. The students had two 60-minute English lessons and one 60-minute multimedia picture book session per week for four weeks with the researcher. This study provided a prototype of lesson plan designs for a group of mixed-level and mixed-age students. Results show that merging games into the teaching content and using 'Game-based Teaching' is significantly suitable for the mixed group. Based on the results, recommendations were provided for both EFL teachers and EFL schools. During lesson plan design, teachers could merge various games into their lessons especially when intended for students of mixed levels. For the schools, it is best to choose teaching materials that combine text with plenty of activities and classroom games.
\end{abstract}

Keywords Action Research, Multiple Intelligence, Game-based Learning, Cooperative Learning, Multimedia Picture Book, English, EFL, Authentic Materials

\section{Introduction}

In Taiwan, it is common practice for public elementary schools to group numerous students into the same class and thus, encompassing a wide range of proficiency levels. This increased the severity of the current learning situation as teachers have to manage the huge gap among its students. This phenomenon has persisted for years and has seemingly gotten worse [3]. In most English classrooms, there are students trained with "bilingual" instruction since kindergarten and on the other hand, are students who are just novice to English. Chang [3] discussed the main reasons that cause this big-gap phenomenon and among them are: (1) location of the schools in urban vs. rural areas, (2) varying socio-economic background of the parents and their degrees of concern, (3) amount of learning resources, (4) values and virtues of the teachers, and (5) students' motivation and interests. Therefore, it would be difficult to find same-level students together in a class. Teachers are constantly confronted with the challenge of how to teach a class with mixed-level students and manage the differences in proficiency level.

Teachers should be aware that the diversity of students' English abilities and Multiple Intelligence (MI) could be used as a framework to design appropriate classroom activities. Gardner [10] proposed the concept of Multiple Intelligences (MI), which includes bodily-kinesthetic, verbal/linguistic, logical/mathematical, musical/rhythmic, interpersonal/social, intrapersonal/introspective, visual/spatial, and naturalist. To illustrate, linguistic intelligence refers to the ability to use words to explain complex meanings effectively. Interpersonal/social intelligence is the ability to communicate, interact, and understand others. Visual/spatial intelligence pertains to the 
ability to perceive visual information accurately and to recreate images. Instead of conceptualizing intelligence as inherited and unitary, Gardner considered MI as eight distinct intelligences that may develop throughout a lifetime. Liu and Chen [17] pointed out that teachers should help students practice English in the classroom while enhancing their MI through activities using picture books, songs, vocabulary, drama, and games. Thus, multimedia picture books, songs and games were streamlined into the children's curriculum. Brown [2 p103] also supported that "Children need to have all five senses stimulated. Your activities should strive to go well beyond the visual and auditory modes that we feel are usually sufficient for a classroom." Play/Game-Based Teaching model has such trait of going beyond the visual and auditory modes. Teachers can use this effectively by designing games according to the characteristics of the children [15].

Thus, this research applied the "Game-Based Teaching" model proposed by Pivec in 2007 [22]. Due to the diversity in years of English learning and age of the participants in this study, the researcher had to create a comfortable learning environment. This reduces their anxiety and increases their interest. Sandford, Ulicsak, Facer, and Rudd [23] indicated that majority of teachers believed games would motivate students' learning. "Game-Based Teaching" would be helpful for those students who have low learning motivations. However, "Teachers need to consider which games to use, when to use them, how to link them up with the syllabus, textbook or program and how, more specifically, different games will benefit students in different ways."'[13] Lin [16] concluded that a successful language game must contain a clear rule, the goal must be well instructed and the game should be fun. The method of Game-Based Teaching motivates children within an atmosphere of enthusiasm, provides opportunities for child-directed instruction, and supports learning with their peers.

Brown [2 p53] defined Cooperative Learning as "students work together in pairs or groups, and they share information and come to each other's aids." It is suggested that when dividing students to do activities, heterogeneous grouping should be used to balance the performance in each group.
The study integrates the theories of Multiple Intelligences (MI), Game-Based Teaching and Cooperative Learning to design a curriculum wherein it encourages students to participate in this program and reduces the pressure of learning. This self-designed curriculum targets groups of students with different levels and aims to deliver significant achievement in a specific classroom.

\section{Method}

\section{Research Design}

With a qualitative research methodology, this study carried out an action research composed of observations and participant interviews - also referred to as the general approach of fieldwork [4]. Denscombe defined that the purpose of an action research is "to solve a particular problem and to produce guidelines for best practice". [5] The action research of this study was to find out whether teachers merged the concepts of MI, Game-Based and Cooperative Learning into their teaching and it was hypothesized that this may be considered as best practice for a group of mixed-level and mixed-age students.

\section{The Framework of Action Research}

In 2010, DeWalt and DeWalt [6] believed that the practice of observing participants provided two main advantages. It does not only enhance the quality of the data obtained, but also the quality of interpretation during fieldwork. Therefore, this research used the Detailed Action Research model (see figure 1) as the framework. First, diagnosing: identifying the serious bipolar phenomenon in elementary schools. Second, action planning: integrating the concepts of Multiple Intelligence (MI), Cooperative Learning and Game-Based Teaching into self-designed lessons. Third, taking action: conducting the treatment on summer intensive English classes. Fourth, evaluating: collecting the reflection, interviews, and observations from the students and the teacher. Fifth, identifying the findings: concluding the results. 


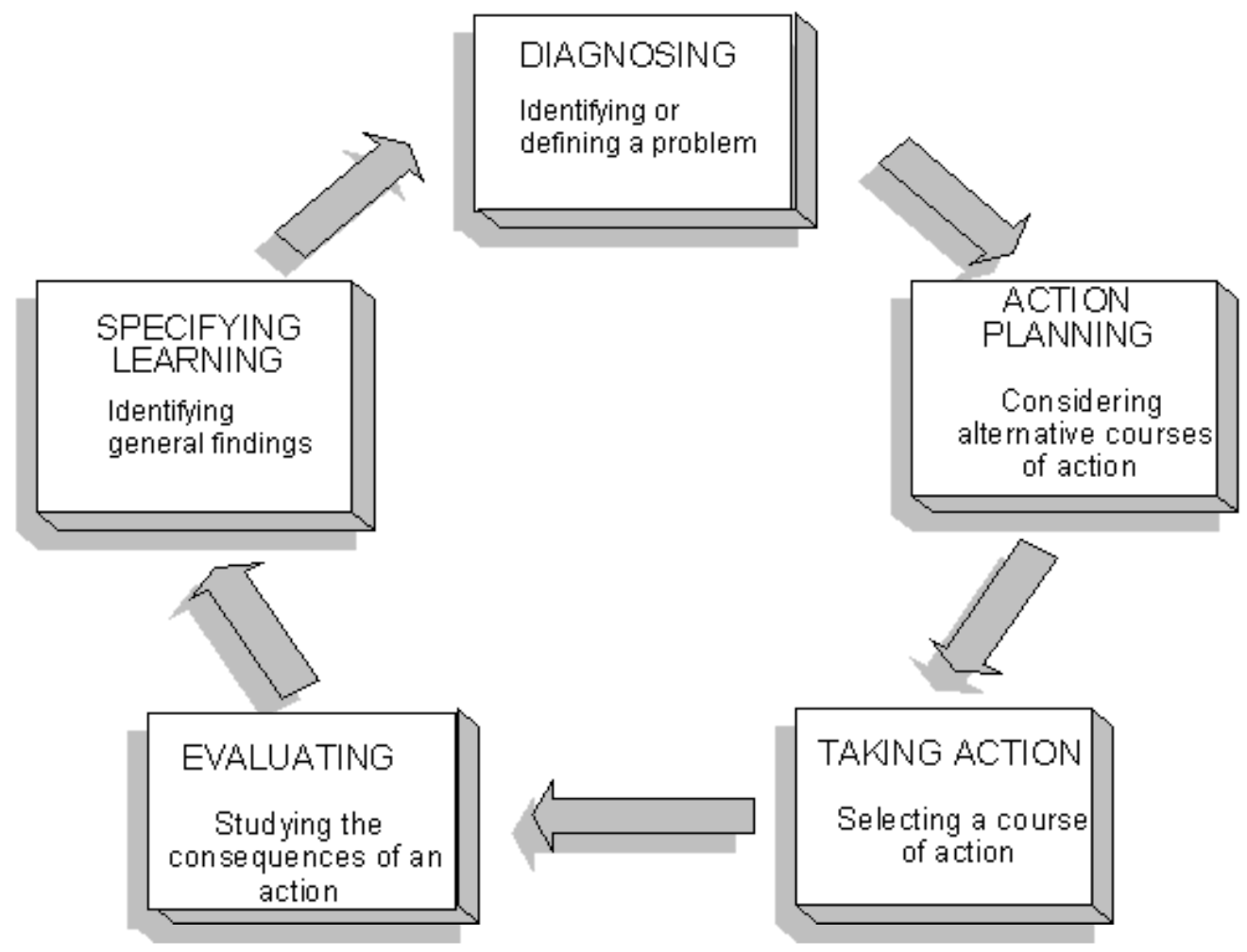

Figure 1. Detailed Action Research Model (adapted from Gerald [25])

\section{Participants}

There were 20 participants in this research, composed of 13 fifth graders and seven sixth graders with equal members of each gender. Out of the sample, only two sixth graders attended cram schools for extra English learning while the rest had the regular Elementary classes. In addition, four of them had difficulty in writing English words, and 10 of them showed little or no confidence in their English abilities. These 14 students appeared anxious during the first lesson when they knew they had to write their English names on cards. Half of the participants did not know how to spell them.

\section{Teaching Procedures}

The Ministry of Education (MOE) started to promote the program of "Students of the University of Schweitzer spiritual teacher education service plan" in all universities. The main purpose of the Schweitzer Program is to provide a chance in Schweitzer spirit. We need to make sure this kind of spirit lasts for pre-service teachers and allow them to teach low-achievement students during summer vacation in a remote and rural public primary school. Most of the students were from either single-parent households or low-income families. This research incorporates the objectives of MOE and is based on "2014 the Schweitzer Program" from August $2^{\text {nd }}$ to $29^{\text {th }}$ with the purpose of encouraging and counseling vulnerable, low-achievement children to improve their English abilities in school. The aim of this research is to know the process and impact of implementing the integration of Multiple Intelligence (MI), Cooperative Learning, and Game-Based Teaching into summer intensive English classes among mixed-level and mixed-age students.

It was challenging to find teaching materials to fit a variety of proficiency levels while facing a budget constraint. It comprised of eight different lessons and the main text was in the form of self-designed PowerPoint presentations, all based on Multiple Intelligence (MI), Cooperative Learning, and Game-Based structures and concepts. It lasted for four weeks, and the lessons included four classes of using multimedia picture books and eight Game-Based lessons. The procedure consisted of a four-phase instructional sequence: roll calls, songs, introductions, and games or activities (see Appendix A). The topics and teaching plans of the lessons are all listed in Appendix B.

\section{Instrument}

\section{Lesson Plans}

Ara [1] reported that children could learn better through fun activities since it takes out the formality of learning a language. Moreover, using songs, rhymes and games can be very effective learning tools that appeal to young learners. Over the 4-week experimental study for Multiple Intelligence, Cooperative Learning and Game-Based lessons, the students had two 60-minute English lessons and one 60-minute multimedia picture books session per week with the researcher. The total instructional learning period 
compassed 4 weeks with a total of 12 hours. The lesson plans are also provided (see Appendices) as a reference for EFL teachers to design lessons for mixed-level groups and mixed-age students in class.

\section{Self-designed PowerPoint Presentations}

The topics were carefully selected according to the competency indicators of elementary students.

\section{Songs}

There were a total of eight different songs selected according to the topics (See Appendix B).

\section{Games}

Games such as "Bingo", "Guessing Games", "Easy Equations" and "Go Fishing" were used to supplement lessons.

\section{Art \& Crafts}

Each class included 30 minutes of storytelling and another 30 minutes for art and crafts activities, which can attract students with visual and bodily-kinesthetic intelligence. For example, after reading the picture book of The Crocodile and the Dentist, students made a giant crocodile replica using a big poster. This way, students were able to use body motions to generate energy and concentration. This activity linked the authentic material and the reading content together by using two senses of learning. Students were good at building things, liked to stay active with their motor skills and were very aware of their bodies. They learn best through movement and experimentation $[21,18]$.

\section{Multimedia Picture books}

Six multimedia picture books were carefully selected as follows: Henny-Penny, The Crocodile and the Dentist, We Are Not Going on a Bear Hunt, Brown Bear, The Very Hungry Caterpillar, and What Do You See. Unlike the paperback picture books, the words on multimedia picture books are easily readable. For instance, after reading the multimedia picture book "The Crocodile and the Dentist" together, participants acted out the story, learned the word "crocodile" and altogether made a giant crocodile replica with a poster. They then had the word that matched with the image of the crocodile. Moreover, both Mayer [19] and Fotos [8] concluded that multimedia help build up a long-term memory (see Figure 2).

In summary, the challenges of teaching mixed-ability and mixed-age classes can be difficult. Figure 3 shows the simplified process of self-design lessons for educators to use when handling a mixed group. It is suggested that using multimedia picture books is a preferable and economical strategy. Another crucial reason was that there was a limited budget for the program; thus, it was not possible to purchase 20 hard copies of each picture book for every student. When designing a curriculum with a limited budget, multimedia picture books would be a good teaching resource. The framework of lesson designs is flexible and easy to follow, such as games, songs, art \& crafts that are all based on the MI concepts for teaching students with different learning styles. Teachers are free to choose one or two activities and incorporate them into self-design lessons. It is not necessary to follow the exact prototype proposed in this study. This research demonstrated some practical and effective ideas on how to make English classes fun and interesting for young learners.

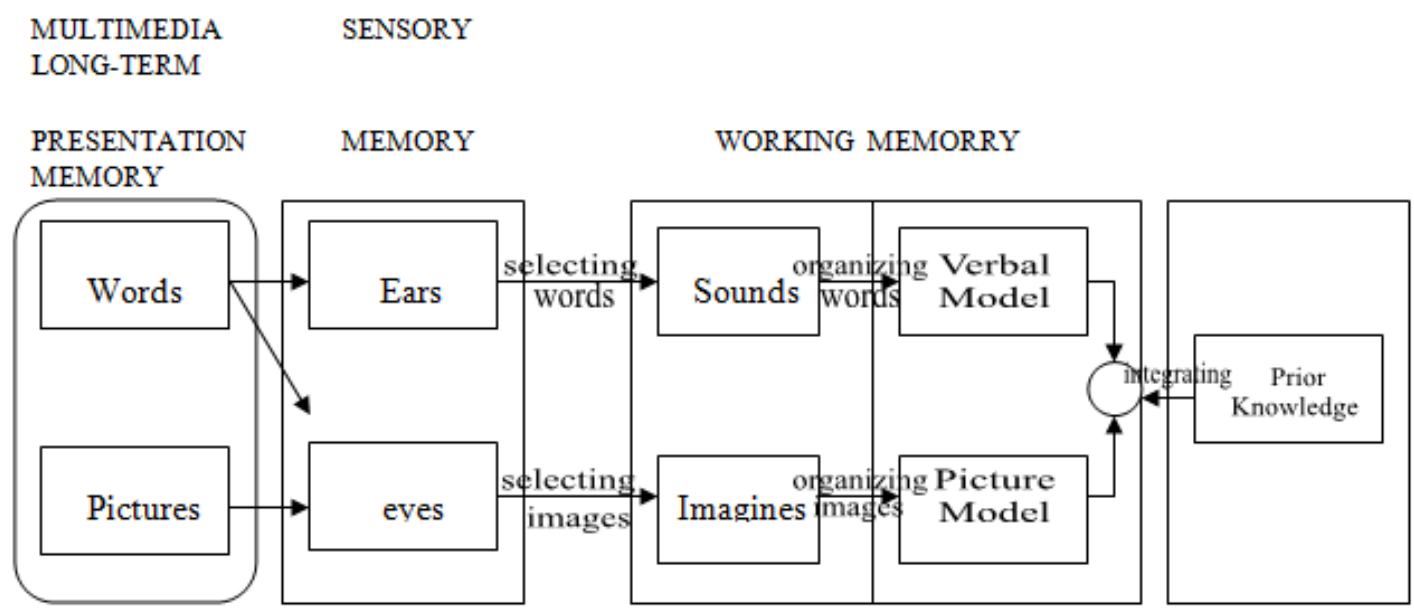

Figure 2. Cognitive theory of multimedia learning. Adapted from "The Cambridge handbook of multimedia learning. Cambridge University Press" by [19] 


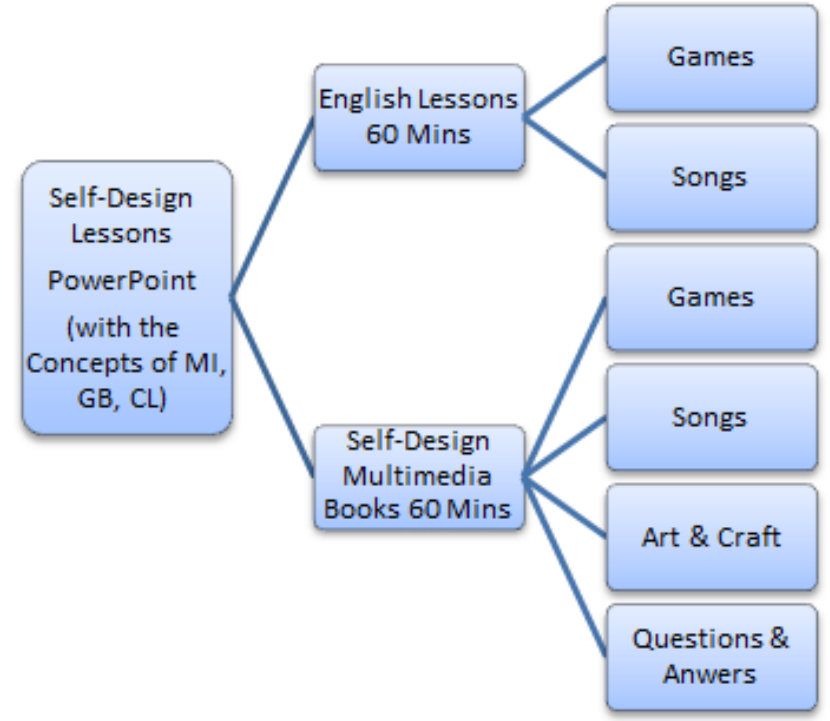

Note. MI=Multiple Intelligence; $G B=$ Game-Based Learning; CL-Collaborative Learning

Figure 3. Chart of design of lessons

\section{Validity and Reliability}

Qualitative research uses a naturalistic approach that seeks to understand the phenomena in context-specific settings, such as "real world setting [where] the researcher does not attempt to manipulate the phenomenon of interest".[20] Patton[20] supported the necessity of the researcher's involvement and immersion into the research wherein before and after events should be properly recorded and presented. The researcher's background consists of teaching experience in both cram schools and elementary schools for a period covering more than 10 years. Together with the research immersion, it was evident that teaching methods must vary to match the students' different needs accordingly. The curriculum needed a thorough change based on the needs and interests of the students, and must include a right amount of useful and fun activities such as singing songs, rhymes and playing games. Pulling from personal teaching experience, it was made clear and certain that students felt more relaxed in a classroom when they did not receive any pressure on learning English.

The type of research that produced findings arrived from real-world settings where the "phenomenon of interest unfold naturally" [20]. To provide constructive feedback and strengthen the reliability of this study, this research was carefully examined by $\mathrm{Dr}$. Su, a professor who has been active on the academic field for 20 years. Her feedback is information-specific, issue-focused, and based on empirical evidence. This included, but not limited to, the identification of strengths/weaknesses and areas for improvement, correction, positive or negative reinforcement to students' behaviors, and forensic diagnosis on the lesson designs of this program.

\section{Teacher's Observations and Reflections}

"Every cognitive act involves an agent who carries out an action or set of actions in some task or domain".[11 p40] Students' actions in class can potentially be evaluated by someone competent such as a teacher in that particular task and domain space. Teachers can examine students' cognitive powers, traits, and temperamental disposition based on bio-psychological perspective. Teachers should check the activities are carried out within societal discipline. Finally, a knowledgeable teacher should provide an evaluation and judgment of these actions [11].

The teacher observed all activities that the students were involved in for a period of 27 days. The researcher took field notes and recorded the reflections on the students' apparent engagement, activities, reactions, and participation. The students were also interviewed individually once during the study. Semi-structured interviews (see Appendix C) were used to ask questions based on class observations. The study set out to know how to integrate MI, Cooperative Learning, and Game-Based teaching into summer intensive English classes among mixed-level and mixed-age students. First, the researcher proposed to simplify all teaching materials and segmented the teaching process for mixed-levels of students. For instance, when teaching the sentence patterns in Lesson Four "What's This?", the teacher made sure to maintain the main sentence pattern until everyone became familiar with it and understood its usage. Subsequently, teachers may also include "What's That?" into their lesson plans.

For the students in class, they could not identify when to use "this" and "that". It is highly recommended to stay in the same topic until all of the students are familiar with the usage of one sentence pattern. Second, set different goals for different levels of students. When asking a question to students of different levels, teachers should establish different sets of expectations. For high-achievement students, the researcher encouraged them to answer the questions by going deeper into detail. This allowed them to take their learning to a higher level. As for the low-achievement and underprivileged students, the goal was to let them understand and respond to questions with words instead of sentences. Third, aside from giving group rewards, the teacher is recommended to also give individual rewards as they serve different purposes. Group rewards are to encourage low-achievement students while personal rewards are to motivate high-achievement students.

In regular classrooms, students with relatively lower abilities are usually silent or distracted during class. However, all students in this program showed positive responses. They were more willing to provide answers in class. It is suggested to apply a method of heterogeneous grouping when teaching mixed-level students. The findings also indicated that the low-achievement students showed less anxiety and seemed to show more interest toward the lessons. The result incorporated with Hooper and Hannafin [12 p1] concluded that "The mixed ability treatment substantially improved the achievement of the low ability students without an accompanying significant reduction in the achievement of the high ability students." 


\section{Results and Discussion}

During the one-hour lesson with game activities, the researcher found out that students paid more attention to the lessons. The use of teaching materials appeared to be effective with students at all achievement levels. Furthermore, they were more enthusiastic in answering questions during class even for low-achievement students. For example, the Bingo game was introduced to increase students' participation by creating excitement. They would not feel tired from studying new words in the classroom and therefore, speak freely using the target language in single words, phrases, or sentences. Li and Zhang [14] indicated that communication activities such as language games, role-playing, and storytelling could be used in an English classroom at elementary level. In addition, there was a positive effect on the achievement and attitudes of students in mixed-age classrooms especially on their attitude toward school, themselves, and others [24].

The findings showed that because games were incorporated into the lessons, students often offered to play games repeatedly. It can be concluded that students had higher interest and increased learning motivation when learning English. When students were confronted with new activities, they paid full attention to the lessons and were very willing to cooperate with their teammates. Collaborative learning is "learning from collaboration", because they perform some activities which trigger some learning mechanisms (induction, deduction, compilation). Peers perform some activities that trigger specific learning mechanisms. This includes the activities/mechanisms performed individually, since individual cognition is not suppressed in peer interaction. The interaction among subjects generates extra activities (explanation, disagreement, mutual regulation,...) which trigger extra cognitive mechanisms (knowledge elicitation, internalization, reduced cognitive load, ...) [7].

Collaborative learning is not a method because of the low predictability of specific types of interactions. Basically, collaborative learning takes the form of instructions to subjects (e.g. "You have to work together"), a physical setting (e.g. "Team mates work on the same table") and other institutional constraints (e.g. "Each group member will receive the mark given to the group project"). Hence, the 'collaborative' situation is a kind of social contract, either among the peers or between the peers and the teacher (then it is a didactic contract). This contract specifies conditions under which some types of interactions may occur, but there is no guarantee they will occur. For instance, the 'collaboration' contract implicitly implies that both learners contribute to the solution, but this is often not the case. Conversely, reciprocal tutoring could be called 'a method', because subjects follow a scenario in which they have to perform particular types of interaction at particular times [7].

Moreover, students asked to repeat most of the games constantly. Game-Based Learning is often experience-based or exploratory, and therefore relies upon experiential, problem-based or exploratory learning approaches [9]. A well-designed game not only reduces the learning pressure but also helps students learn the target vocabulary or sentence patterns more efficiently. When interviewing students with the following questions:

1. How do you feel when you are in English class?

2. What is your favorite activity?

3. Do you like English class?

4. When you encounter problems, what will you do?

5. Please list sentences you learned in class.

The researcher received the following reflections from students:

- Songs are my favorite. I love singing and do the movement (s01).

- I love Bingo game. It is very exciting (s010).

- I like making crocodile with a piece of paper. It is so cool (s03).

- I do not have a favorite because I love all of them (s011).

- When I had questions about the activities, my leader always explained it to me (s14).

- I Io not feel anxious like I did in English class (s13).

The findings above are all positive. When participants were asked a to write the sentences that they had learned during the lessons, all of them could recall at least three sentences patterns even for the low-achievement ones. Nonetheless, for some students, they had difficulties to spell some words, such as this, like...etc.

Surprisingly, the researcher did not encounter any difficulties when teaching a mixed-age group. However, it was the process of preparing teaching materials and selecting suitable multimedia picture books and songs that took most of the time. The results provide that among all the games, the Bingo game was the one that participants enjoyed the most. As for one-hour multimedia picture books with art and crafts making, participants loved the part of art \& craft making after the story, "the existence of apraxia constitutes one line of evidence for a bodily-kinesthetic intelligence, is an evidence of the cognitive features of body usage" [11] and also students loved the songs. The results are aligned with Pivec [22 p387]" Many of us have grown up playing games, and in primary education games have a high presence in formal and informal segments of our learning." It is critical to take out the pressure within the learning environments to reduce their anxiety and gradually increase their learning interest.

\section{Conclusions}

The mixed-age classroom was set up because of budget constraints. It was compulsory to combine students of different ages in a single classroom because the district could not afford to hire additional teachers, or because of the declining enrollment rate that often occurred in rural districts. This situation gives rise to negative attitudes as a result of not being prepared and not having the proper academic materials to meet the needs of all students. Courses taught in a mixed 
age group is more challenging $\mathrm{h}$ problematic than in a regular class of the same age. It requires more perseverance, patience, planning and love for children. When designing the activities/games in class, the concept of Multiple Intelligence (MI), Game-Based, and Cooperative Learning helped to plan suitable lessons to fit all students' learning styles. For example: songs for audio learners, guessing game for visual learners, and equations for mathematical learners. As a whole, it is recommended to assign a more able and more experienced teacher to the mixed-age classroom in order to effectively manage the variety of children's abilities. One of the significant results from this study is that the incorporation of games into teaching or using Game-Based instruction may be an appropriate solution for a group of mixed-level and mixed-age students. Based on the results of the study, EFL teachers are suggested to carefully design a lesson plan that combines games and teaching. When designing teaching materials, it is better to provide a variety of helpful games that are related to the topic. Most importantly, when doing remedial teaching for low proficiency students, results showed that games not only motivated students' learning but also reduced their anxiety. Furthermore, apart from the paperback books, using self-designed PowerPoint presentations had a great positive effect. It does not only answer the budget constraint but also fit the students' abilities accordingly as the teacher can easily rearrange the text.

In Taiwan, a senior student's English ability doesn't guarantee that he/she is better than a younger student. It still depends on how long the student has learned English. Therefore, teaching a group of mixed-age students can be challenging, but there are several ways that you can work with this situation and have an enjoyable and successful time for all of the students involved. The study provided some tips for mixed age classes. First, invite the students' parents to help out. For example, teachers can be specific to let parents know what assistance you will need and what you would like them to do outside of class. Especially, for those younger learners who need more parents' assistance. Second, teachers can ask the older kids to act as mentors or as teacher's assistants. This allows the older kids to have the opportunity to lead younger students and reinforce their learning. Students may be working with different materials, such as art and crafts or worksheets with the mixed group and the teacher won't have as much time to spend helping all the younger students. In this situation, there is a good chance to let the older learners help out the younger children, and generally those younger children will look up to the older students. While playing games like Matching in teams with one older child and one younger child paired together to match picture cards to word cards together, it is a pleasure to see them help one another and teach each other.

Third, encourage everyone to participate in all the activities and use flexible teaching materials. For example, picture books, stories, crafts, and songs are great for kids of a variety of ages. Because of the illustrations, crafts and lyrics are great materials to help attract young learners. By using picture books, crafts, and songs that are simple enough for very young children and entertaining enough for older learners of all levels, all of the students can join in these activities. Fourth, teachers can interact with each of the students by asking them questions and giving them tasks that are appropriate for their levels. For example, if you have students who are readers, have them help you read and answer your questions. The study emphasizes the concepts of MI, Game-Based learning and Collaborative Learning that is important because not only are children working on important collaboration and social/emotional skills, but also they will help build a child's confidence and interest in those learning domains.

The finding showed that the integration games or activities into the curriculum require the experience in selecting suitable games to students of different levels. It is suggested that English teachers should consider the learning of the target languages first, then develop suitable (activities/games) to assist the language learning. Most elementary school teachers were limited by the textbooks and kept traditional ways of not developing games or activities because they thought the latter was a waste of time. In conclusion, teaching experience is a key factor for successful teaching. In the design of teaching activities, the main focus is to allow students to learn the target language. Interesting and fun activities are only incidental and supplementary for assisting their learning. It is important to examine the way in which mixed-age grouping is implemented in a particular class. It is suggested that the mixed-age program must be carefully designed, and teachers who teach in these classrooms are required to be well prepared for the curricular materials and trainings necessary to effectively teach in type of setting. Through time, patience, careful observations, and flexibility of lesson designs, teachers can use these tips to successfully balance how to teach with mixed ages. Future studies can conduct a similar research method but covering a longer period of time to generate a detailed observation report and more thorough analysis.

\section{Appendices}

\section{Appendix A}

Teaching Procedures

1. Roll call (5minutes).

Throughout calling their names, to get them know and used to hear each other's names better. The instructor may also give greetings at this period.

2. Song (10 minutes)

Songs are careful selected to relate to the topics were introduced each time; also design some movements to help students memorize the lyric better.

3. Introduction (15 minutes).

The instructor presents a new task topic, such as vocabulary or sentence patterns. 
4. Games and activities (30 minutes).

Students are divided into two groups to compete and each group would have to answer or reach the goal that the instructor set for each lesson.

\section{Appendix B}

\begin{tabular}{|c|c|}
\hline \multicolumn{2}{|r|}{ Lesson Plan (Lesson 1 to Lesson 4) } \\
\hline Lesson 1-8 & Teaching Procedure \\
\hline \multicolumn{2}{|l|}{ Lesson 1} \\
\hline I want to get to know you!! & $\begin{array}{l}\text { 1. Sing Hello Song: } \\
\text { http://www.youtube.com/watch?v=eBF9DxxAfkU } \\
\text { 2. Using PowerPoint instead of textbook and print out name cards to give every student. (See appendix A and B) } \\
\text { 3. Ask students to write their names on the cards, and write down a basis introduction using the sentence patterns } \\
\text { showed on the } 3^{\text {rd }} \text { slide. } \\
\text { 4. Encourage students to come to the stage to read their self-introductions. }\end{array}$ \\
\hline \multicolumn{2}{|l|}{ Lesson 2} \\
\hline Phonics Fun & $\begin{array}{l}\text { 1. Sing ABC Song: } \\
\text { https://www.youtube.com/watch?v=j2hazzQ5bSs } \\
\text { 2. Introduce the sounds and the letters. } \\
\text { 3. Teaching students to combine sounds and pronounce the words. } \\
\text { 4. Bingo game (See appendix C). }\end{array}$ \\
\hline \multicolumn{2}{|l|}{ Lesson 3} \\
\hline It's a /an & $\begin{array}{l}\text { 1. Song: It's a/ an } \\
\text { http://www.youtube.com/watch?v=tNK0ToOgntw 2. Teaching the target words: box, ox, umbrella, apple, van. } \\
\text { And the correct usage of a/ an. } \\
\text { 3. List more nouns for students to put a/ an. }\end{array}$ \\
\hline \multicolumn{2}{|l|}{ Lesson 4} \\
\hline What's this? & $\begin{array}{l}\text { 1. Song: What's this? } \\
\text { https://www.youtube.com/watch?v=wX9117iMwK0 } \\
\text { 2. Teaching the target sentence: What's this? And also review the vocabulary taught in Lesson } 3 . \\
\text { 3. Let students guess the words showed on the slides. }\end{array}$ \\
\hline \multicolumn{2}{|c|}{ Lesson Plan (lesson 5 to Lesson 8) } \\
\hline Lesson 1-8 & Teaching Procedure \\
\hline \multicolumn{2}{|l|}{ Lesson 5} \\
\hline Numbers $1-100$ & $\begin{array}{l}\text { 1. Song: Number song. } \\
\text { https://www.youtube.com/watch? } v=\mathrm{e} 0 \mathrm{dJWfQHF} 8 \mathrm{Y} \\
\text { 2. Teaching numbers and also plus and minus. } \\
\text { 3. Giving each group some easy equations for students to calculate and then say the answers. }\end{array}$ \\
\hline \multicolumn{2}{|l|}{ Lesson 6} \\
\hline Do you have __ ? & $\begin{array}{l}\text { 1. Song: } \\
\text { https://www.youtube.com/watch?v=mef1gsdSu_I } \\
\text { 2. Introduce the sentence pattern "Do you have__?" } \\
\text { And also the rules of the card games } \\
\text { 3. } 4 \text { students in each group to ask each other the questions by playing cards. } \\
\text { The student who gets more pairs of the cards, wins the game. }\end{array}$ \\
\hline \multicolumn{2}{|l|}{ Lesson 7} \\
\hline How many ___ are there? & $\begin{array}{l}\text { 1. Song: } \\
\text { https://www.youtube.com/watch?v=G3zaC5onBvM } \\
\text { 2. Introduce the sentence paten "How many } \_ \text {are there?" and then also review numbers. } \\
\text { 3. Practice the sentence by guessing the numbers of the items in my bag. }\end{array}$ \\
\hline \multicolumn{2}{|l|}{ Lesson 8} \\
\hline Jump, Jim, Joe & $\begin{array}{l}\text { 1. Song: Jim, Jim Joe } \\
\text { https://www.youtube.com/watch?v=60mVmu3qqvk } \\
\text { 2. Introduce the lyrics and also do the movements. } \\
\text { 3. Sing the song and dance. }\end{array}$ \\
\hline
\end{tabular}




\section{Appendix C}

Interview Questions

1. How do you feel when in English class?

2. What is your favorite activity?

3. Do you like English class?

4. When you encounter problems, what do you do?

5. Please list sentences you learned in class.

\section{REFERENCES}

[1] S. Ara, "Use of Songs, Rhymes and Games in Teaching English to Young Learners in Bangladesh," Dhaka Univ. J. Linguist., vol. 2, no. 3, pp. 161-172, 2009.

[2] D. Brown, Principles of Language Learning and Teaching. 2007.

[3] V. W. Chang, "English Language Education in Taiwan: A Comprehensive Survey," Educ. Resour. Res., no. 69, pp. 129144, 2006

[4] J. Delong, C. Griffin, E. Campbell, and J. Whitehead, "The significance of living-theory action research in a culture of inquiry transforms learning in elementary, high school and post-graduate settings," Educ. J. Living Theor., vol. 6, no. 2, pp. 78-96, 2009.

[5] M. Denscombe, Good Research Guide: For Small-Scale Social Research Projects, 4th ed. 2014.

[6] K. M. DeWalt and B. R. DeWalt, Participant Observation: A Guide for Fieldworkers, 2nd ed., no. Book, Whole. AltaMira Press, 2010.

[7] P. Dillenbourg, "What do you mean by collaborative learning?," in Collaborative-learning: Cognitive and Computational Approaches, Oxford: Elsevier, 1999, pp. 1-19.

[8] S. Fotos, Multimedia Language Teaching. Tokyo and San Francisco: Logos International, 1996.

[9] S. de Freitas, "Learning in immersive virtual worlds: A review of game-based learning," 2006.

[10] H. Gardner, Frames of mind: the theory of multiple intelligences. New York: Basic Books, 1983.

[11] H. Gardner, Multiple Intelligences: New Horizons in Theory and Practice. New York: Basic Books, 2006.
[12] S. Hooper and M. J. Hannafin, "Cooperative Learning at the Computer: Ability Based Strategies for Implementation.," in Annual meeting of the Association for Education Communication \& Technology, 1988.

[13] J. Khan, "Using games in teaching English to young learners," in Teaching English to children : From practice to principle, C. Brumfit, Ed. England: Longman, 1996, pp. 48-61.

[14] X. Li and M. Zhang, "Why Mei Still Cannot Read and What Can Be Done," J. Adolesc. Adult Lit., vol. 48, no. 2, pp. 92101,2004

[15] P. Liao, The Handbook of Research Papers Writing. Taipei, Taiwan: Jong Wen Books Co., Ltd., 2006.

[16] Hong Lin, "Using games in teaching English to young learners," Internet TESL J., vol. 8, no. 8, 2002.

[17] H. Liu and T. Chen, "Foreign language anxiety in young learners: How it relates to multiple intelligences, learner attitudes, and perceived competence," J. Lang. Teach. Res., vol. 4, no. 5, pp. 932-938, 2013.

[18] A. Loh, "What is Bodily-Kinesthetic Intelligence?" [Online]. Available: http://www.brainy-child.com/articles/bodily-kinesthetic-intell igence.shtml.

[19] R. E. Mayer, Ed., The Cambridge Handbook of Multimedia Learning. 2005.

[20] M. Patton, Qualitative evaluation and research methods, 3rd ed. Thousand Oaks, CA: Sage Publications, Inc., 2002.

[21] "Personality Max." [Online]. Available: https://mypersonality.info/multiple-intelligences/bodily-kines thetic/.

[22] M. Pivec, "Editorial: Play and learn: Potentials of game-based learning," Br. J. Educ. Technol., vol. 38, no. 3, pp. 387-393, 2007.

[23] R. Sandford, M. Ulicsak, K. Facer, and T. Rudd, Teaching with Games: Using commercial off-the-shelf computer games in formal education. Bristol: Futurelab, 2006.

[24] S. J. Stone, "Creating the Multiage Classroom.," Focus Elem., vol. 10 , no. 3, 1996.

[25] G. Susman, "Action Research: A sociotechnical Systems Perspective.," in Beyond Method: Strategies for Social Science Research, G. Morgan, Ed. London: SAGE Publications, 1983, pp. 95-113. 